\title{
KONSERVASI DAN PEMBERDAYAAN PENGELOLAAN SISTEM PEMBANGKIT LISTRIK ALTERNATIF PLTS, PLTMH DI KECAMATAN BULANGO ULU KABUPATEN BONE BOLANGO, GORONTALO
}

\section{Conservation And Empowerment Of Alternative Plts, Pltmh Power Plant Management System In Bulango Ulu District, Bone Bolango District, Gorontalo}

\author{
Burhan Liputo $^{1)}$, Mustofa ${ }^{2)}$, Yunita Djamalu ${ }^{3)}$, Evi Sunarti Antu ${ }^{4}$ \\ ${ }^{1,2,3,4)}$ Dosen Program Studi Mesin dan Peralatan Pertanian, Politeknik Gorontalo \\ e-mail: tofamoes4965@gmail.com
}

\begin{abstract}
ABSTRAK
Desa Pilolaheya dan Desa Suka Makmur telah memiliki sistem pembangkit listrik terbarukan yaitu PLTS terdapat di desa Pilolaheya dan PLTMH di desa Suka Makmur. Sistem pembangkit yang memanfaatkan energi terbarukan ini sudah dioperasikan dan digunakan oleh warga desa Pilolaheya dan Suka Makmur untuk berbagai aktivitas kebutuhan warga desa tersebut. Persoalan yang dihadapi adalah dari aspek konservasi sumber energi yang dimanfaatkan pada sistem pembangkit secara teknis belum dapat dipahami masyarakat desa Pilolaheya dan Suka Makmur sehingga kepedulian untuk melakukan kegiatan konservatif baik secara personal warga ataupun secara bersama belum terwujud. Hal ini dapat berdampak pada eksistensi dan keberlanjutan pengoperasian sistem pembangkit yang digunakan dan aspek pemberdayaan masyarakat terutama pengelolaan dan pemeliharaan sistem pembangkit listrik yang digunakan. Penyebabnya karena secara teknis masih mengandalkan intervensi pemerintah, sehingga dapat berdampak pada sifat ketergantungan masyarakat itu sendiri. Solusi dari persoalan konservasi sumber energi pada pembangkit PLTS dan PLTMH adalah pembinaan pengetahuan dan pemahaman masyarakat desa tersebut. Pembinaan ini berkaitan dengan konservasi sumber energi secara teknis dan praktis. Adapun solusi persoalan pemberdayaan dan pengelolaan sistem pembangkit PLTS dan PLTMH adalah pembelajaran praktis pengenalan sistem pembangkit, pengelolaan dan pemeliharaan, penanganan kerusakan komponen sistem dan teknik penghematan pemakaian daya beban listrik PLTS. Kegiatan Pengabdian kepada Masyarakat ( $\mathrm{PkM}$ ) dimaksudkan untuk solusi-solusi tersebut. Kegiatan PkM ini dilaksanakan melalui beberapa tahapan, yaitu survei kondisi desa, koordinasi pemerintah desa, sosialisasi pendahuluan, sosialisasi pelaksanaan dan pelaksanaan kegiatan dan pelatihan. Berdasarkan hasil PkM diperoleh hasil bahwa masyarakat secara umum telah mengetahui dan memahami bagaimana seharusnya pengelolaan sistem pembangkit listrik alternatif tersebut.
\end{abstract}

Kata Kunci: PLTMH, PLTS, konservasi, pemberdayaan, energi

\section{ABSTRACT}

Pilolaheya and Suka Makmur villages have a renewable power generation system, namely PLTS found in Pilolahey a village and PLTMH in Suka Makmur village. The generator system that utilizes renewable energy has used and operated by Pilolaheya and Suka Makmur villagers for various activities the villagers need. The problem faced by the aspect of conserving energy sources that are utilized in the generating system technically. It cannot be understood by the people of Pilolaheya and Suka Makmur villages so that the concern to carry out conservative activities both personally and collectively has not yet been realized. It can have an impact on the existence and sustainability of the operation of the generating system used and aspects of community empowerment, especially the management and maintenance of the power plant system used. The reason is that technology still relies on government intervention so that it can have an impact on the nature of community dependence itself. The solution to the problem of conserving energy sources in PLTS and PLTMH plants is to foster the knowledge and 
understanding of the village community. This guidance is related to the conservation of energy sources, technically and practically. The solution to the problem of empowerment and management of PLTS and PLTMH generating systems is practical learning of the introduction of creating operations, management and maintenance, handling damage to system components, and techniques for saving the use of PLTS electricity. Community Service (PkM) activities intended for these solutions and carried out through several stages, namely survey of village conditions, coordination of village government, preliminary socialization, socialization of the implementation, and implementation of activities and training. Based on the results of the PkM. It obtained that the community, in general, had known and understood how the alternative power generation system should manage

\section{Keywords: PLTMH, PLTS, conservation, empowerment, energy}

\section{PENDAHULUAN}

$\begin{array}{ccc}\text { Wilayah yang menjadi lokasi } \\ \text { pelaksanaan } & \text { pengabdian } & \text { kepada }\end{array}$
masyarakat adalah wilayah kecamatan Bulango Ulu yang difokuskan pada dua desa yaitu desa Pilolaheya dan desa Suka Makmur kabupaten Bone Bolango. Kecamatan Bulango Ulu memiliki luas wilayah $78,41 \mathrm{~km}^{2}$ atau $3,95 \%$ dari luas wilayah kabupaten Bone Bolango. Hingga saat ini semua desa yang ada di wilayah kecamatan Bulango Ulu termasuk desa Pilolaheya dan Suka Makmur hanya memanfaatkan sumber energi terbarukan terutama air dan matahari yang digunakan sebagai sumber pembangkit tenaga listrik PLTM. Gambar 1 merupakan presentase luas wilayah desa berdasarkan luas wilayah kecamatan Bulango Ulu yakni 78,41 km².

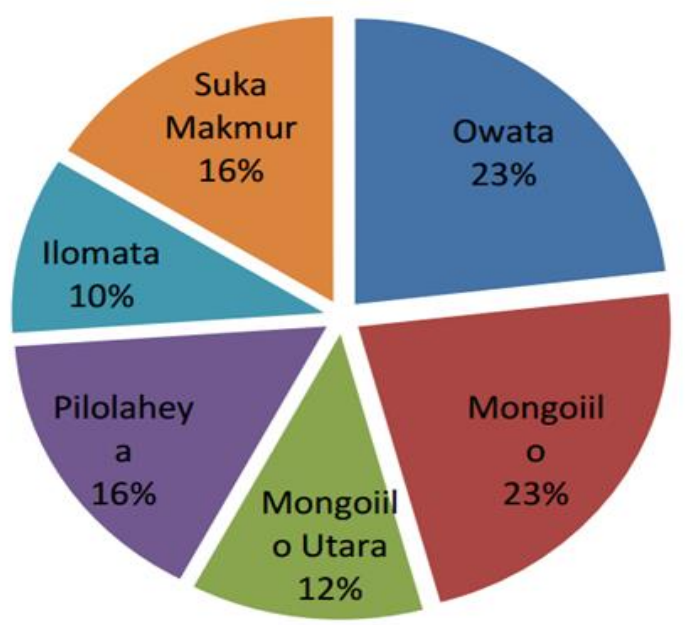

Gambar 1. Presentasi luas wilaya desa sekecamatan Bulango Ulu (BPS Bone Bolango, 2016)

Jarak desa Suka Makmur dari pusat kabupaten Bone Bolango $33 \mathrm{~km}$ dan dari pusat kecamatan Bulango Ulu berjarak $8 \mathrm{~km}$. Desa Suka Makmur terdiri dari tiga dusun yakni dusun Sandanaya, Molongiyo dan Oluhuta. Desa ini berpenduduk 391 jiwa, 105 KK, dengan Jumlah bangunan rumah adalah 83 rumah. Organisasi kemasyarakatan yang ada di desa adalah BPD, kelompok tani dan karang taruna Suka Maju. Secara umum sumber pencaharian masyarakat desa Suka Makmur adalah sebagai petani jagung dan pembuat gula aren. Secara infrastruktur desa ini memiliki bangunan sekolah PAUD satu unit, sekolah TK satu uni, sekolah SD satu unit, sekolah SLTP satu unit, PUSKESDES satu unit, pembangkit listrik PLTM satu unit dan kantor desa satu unit.

Desa Pilolayeha dan desa Suka Makmur telah memiliki sistem pembangkit listrik terbarukan yaitu PLTS terdapaat di desa Pilolaheya dan PLTMH di desa Suka Makmur (Gambar 2). Sistem pembangkit yang memanfaatkan energi terbarukan ini sudah dioperasikan dan digunakan oleh warga desa Pilolaheya dan Suka Makmur untuk berbagai aktivitas kebutuhan warga desa tersebut.

Kapasitas daya bangkit PLTS di desa Pilolaheya mencapai $15 \mathrm{~kW}$ terpusat yang melayani 72 rumah warga dengan daya sambung untuk masing-masing rumah adalah sebesar 200 W. Sistem pembangkit ini dibangun pada tahun 2016 dan dioperasikan pada tahun itu juga yang penggunaanya hingga saat ini. Sistem pembangkit PLTS di desa Pilolaheya merupakan satu-satunya pembangkit listrik yang digunakan warga untuk berbagai keperluan kebutuhan dan aktivitas sehari-hari. 


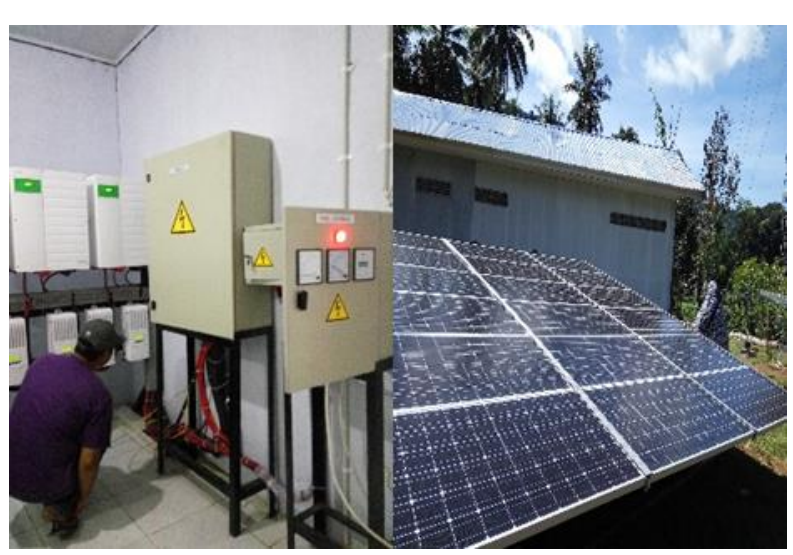

Gambar 2. Sistem PLTS terpusat di desa Pilolaheya

Kegiatan pengabdian ini dimaksudkan untuk memberikan pemahaman kepada masyarakat tentang mekanisme dan tata cara pengelolaan sistem pembangkit listrik alternatif. Disamping itu, kegiatan PkM ini juga bertujuan untuk mengetahui sejauh mana kemampuan masyarakat dalam pemberdayaan pengelolaan sistem pembangkit listrik alternatif.

\section{Permasalahan Mitra}

a. Kondisi Wilayah dan Prioritas Masalah

Desa Pilolaheya dan desa Suka Makmur adalah termasuk daerah pedalaman di kabupaten Bone Bolango dan memiliki pembangkit listrik berskala mikro atau PLTM dengan memanfaatkan energi terbarukan berupa tenaga matahari dan tenaga air. Pada konteks tanggung jawab pemerintah dalam hal ini adalah membangun sarana untuk memenuhi kebutuhan listrik bagi masyarakat desa pedalaman khususnya desa Pilolaheya dan Suka Makmur, sudah dilakukan dan akan terus dilakukan. Desa Pilolaheya telah dibangun pembangkit listrik PLTS terpusat berkapasitas $15 \mathrm{~kW}$ dan desa Suka Makmur berupa pembangkit listrik PLTMH dengan kapasitas $12 \mathrm{~kW}$.

Pada aktivitas penggunaan dan penanganan pemeliharaan sistem pembangkit di dua desa ini, terdapat persoalan sedang dihadapi pemerintah terutama bidang konservasi sumber daya energi dan pemberdayaan masyarakat. Persoalanpersoalan dimaksud adalah sebagai berikut:

1. Aspek konsevasi sumber energi yang dimanfaatkan pada sistem pembangkit secara teknis belum dapat dipahami masyarakat desa Pilolaheya dan Suka Makmur sehingga kepedulian untuk melakukan kegiatan konservatif baik secara personal warga ataupun secara bersama belum terwujud. Hal ini dapat berdampak pada eksistensi dan keberlanjutan pengoperasian sistem pembangkit yang digunakan.

2. Aspek pemberdayaan masyarakat terutama pengelolaan dan pemeliharaan sistem pembangkit listrik yang digunakan, secara teknis masih mengandalkan intervensi pemerintah, sehingga dapat berdampak pada sifat ketergantungan masyarakat itu sendiri.

\section{b. Permasalahan Prioritas}

Masalah prioritas sebagai berikut:

1. Masalah konservasi sumber energi pada pembangkit PLTS dan PLTMH di Desa Pilolaheya dan Suka Makmur Kecamatan Bulango Ulu.

2. Masalah pemberdayaan masyarakat dalam pengelolaan sistem pembangkit PLTS dan PLTMH di desa Pilolaheya dan Suka Makmur.

\section{SOLUSI DAN TARGET LUARAN}

\section{Solusi Permasalahan}

Solusi persoalan konservasi sumber energi pada pembangkit PLTS dan PLTMH antara lain:

1. Pembinaan pengetahuan dan pemahaman masyarakat desa Pilolaheya dan Suka Makmur tentang konservasi sumber energi secara teknis dan praktis.

2. Pelatihan pembelajaran praktis mengenai teknik konsevasi pemanfaatan energi matahari dan energi air.

3. Pelatihan penanganan dampak kerusakan lingkungan dalam pengoperasian dan penggunaan sistem pembangkit listrik PLTS dan PLTMH.

Solusi persoalan pemberdayaan dan pengelolaan sistem pembangkit PLTS dan PLTMH diantaranya:

1. Pembelajaran praktis pengenalan sistem pembangkit PLTS dan PLTMH.

2. Pelatihan teknik penanganan gangguan fungsi sistem pembangkit PLTS dan PLTMH. 
3. Pelatihan teknik pengelolaan dan pemeliharaan sistem PLTS dan PLTMH.

4. Pelatihan teknik identifikasi dan penanganan kerusakan komponen sistem pembangkit PLTS dan PLTMH.

5. Pelatihan teknik penghematan pemakaian daya beban listrik secara mandiri.

\section{Luaran dan Target Capaian}

Jenis luaran kegiatan PkM ini antara lain:

1. Publikasi jurnal nasional ber-ISSN.

2. Membuat draft buku.

3. Peningkatan kualitas dan kesejahteraan masyarakat Desa Pilolaheya dan Desa Suka Makmur.

Target capaian yang akan dihasilkan:

1. Menumbuhkan sikap kepedulian masyarakat desa Pilolaheya dan Suka Makmur dalam menjaga dan melestarikan sumber energi terutama yang dimanfaatkan pada pembangkit listrik PLTS dan PLTMH.

2. Membangun kebersamaan masyarakat dalam mencegah dampak lingkungan akibat pengoperasian sistem pembangkit PLTS dan PLTMH.

3. Menigkatkan pengetahuan dan pemahaman pengelolaan sistem pembangkit PLTS dan PLTMH kepada masyarakat desa Pilolaheya dan Suka Makmur.

4. Menanamkan kemandirian masyarakat dalam penanganan sistem pembangkit PLTS dan PLTMH.

5. Membangun kebersamaan warga desa dalam pengelolaan dan pemeliharaan sistem pembangkit PLTS dan PLTMH.

6. Meningkatkan keterampilan masyarakat dalam aktivitas perbaikan sistem pembangkit.

7. Menumbuhkan kesadaran penggunaan daya listrik secara bijak dan terukur kepada masyarakat desa Pilolaheya dan desa Suka Makmur.

\section{PELAKSANAAN KEGIATAN}

Kegiatan Pengabdian kepada Masyarakat dilaksanakan di Kecamatan Bulango Ulu, tepatnya di Desa Suka Makmur dan Pilolaheya. Kegiatan PkM ini dilaksanakan oleh Tim Pengabdian dari Prodi Mesin dan Peralatan Pertanian Politeknik Gorontalo.

\section{Tahapan-tahapan Pelaksanaan PkM}

Kegiatan PkM dilaksanakan melalui beberapa tahapan, diantaranya:

1. Survei Kondisi Desa

Desa Pilolaheya dan Suka Makmur sebagai lokasi pelaksanaan kegiatan akan dilakukan survei pendahuluan untuk mengamati kondisi wilayah desa ini terutama dalam kaitannya dengan masalah pemanfaatan dan pengelolaan sumber energi pada pembangkit listrik PLTS dan PLTM.

2. Koordinasi Pemerintah Desa

Pelaksanaan kegiatan pengabdian kepada masyarakat akan dikoordinasikan dengan pihak pemerintah desa Pilolaheya dan Suka Makmur terutama maksud dan tujuan kegiatan, bentuk kegiatan, waktu dan materi kegiatan. Hal ini dimaksudkan untuk kelancaran kegiatan yang diusulkan.

3. Sosialisasi Pendahuluan

Perlunya temu muka bersama warga desa Pilolaheya dan Suka Makmur untuk mensosialisasikan kegiatan dimaksud sehingga akan terbangun komunikasi pendahuluan dalam melaksanakan kegiatan ini.

4. Sosialisasi Pelaksanaan

Agar pelaksanaan kegiatan pengabdian kepada masyarakat dapat dilakukan tepat waktu maka semua yang akan dilaksanakan baik jadwal kegiatan, waktu, materi dan semua yang terkait akan disosialisasikan ke masyarakat. Sehingga semua persiapanpersiapan baik oleh masyarakat maupun pelaksana kegaiatan dapat dilakukan dengan baik.

5. Pelaksanaan Kegiatan dan Pelatihan

Secara umum kegiatan pengabdian kepada masyarakat yang akan dilaksanakan di desa Pilolaheya dan Suka Makmur dapat berupa pembelajaran praktis tentang koservatif dan pelatihan teknis untuk memberdayakan masyarakat dalam pemeliharaan dan penanganan sistem pembangkit PLTS dan PLTMH.

Tahapan-tahapan di atas disajikan dalam bentuk diagram alir pengabdian sebagaimana dapat dilihat pada Gambar 3. 


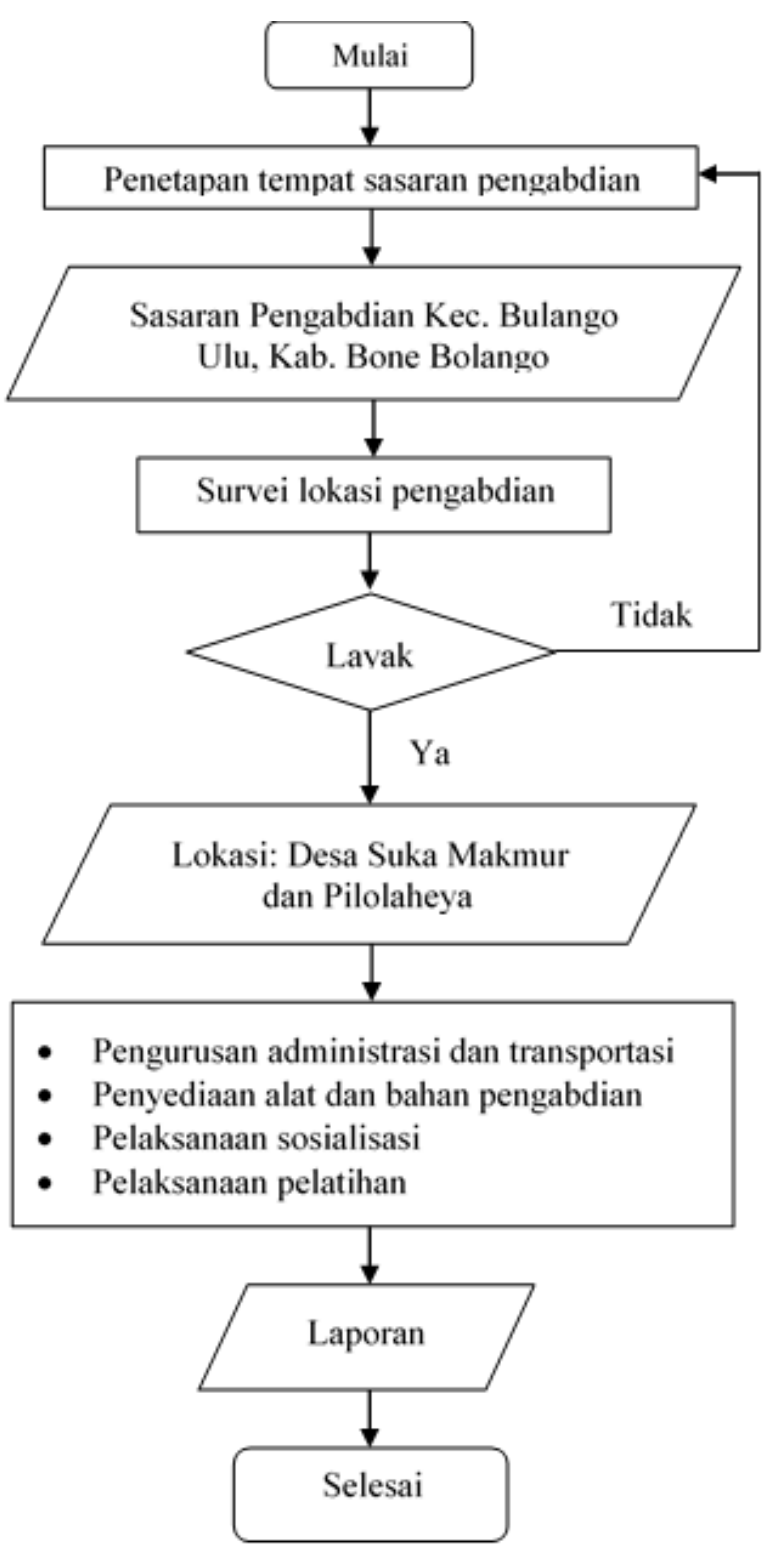

Gambar 3. Diagram Alir Kegiatan Pengabdian

\section{Pelaksanaan Kegiatan}

Pelaksanaan kegiatan PkM di Kecamatan Bulango Ulu sebagaimana dilakukan melalui kegiatan-kegiatan berikut.

1. Pendahuluan. Pendahuluan dilakukan dengan pengusulan proposal PkM.

2. Persiapan. Langkah-langkah yang dilakukan pada tahap persiapan yaitu penyediaan Alat dan Bahan, meliputi spanduk, Buku Pedoman Pengelolaan Sistem Pembangkit Listrik, Materi pengabdian, dan perangkat sosialisasi seperti Laptop dan LCD.

3. Pelaksanaan, dilakukan dengan kegiatankegiatan seperti:
- Penyampaian pendahuluan (pembukaan) oleh Kepala Desa Suka Makmur.

- Penyampaian materi oleh Ketua Tim Pengabdian tentang Pengelolaan Sistem Pembangkit Listrik Alternatif.

- Diskusi dan Tanya jawab.

- Pelaksanaan pelatihan pengelolaan sistem pembangkit listrik alternative

\section{Tempat, Waktu dan Peserta Kegiatan}

Kegiatan PkM ini dilaksanakan di Kantor Desa Suka Makmur Kecamatan Bulango Ulu pada Tanggal 14 Agustus 2018 pukul 10.00 13.00 WITA. Kegiatan ini dihadiri oleh masyarakat Kecamatan Bulango Ulu, terutama masyarakat Desa Suka Makmur. Perserta yang mengikuti kegiatan PkM sebanyak 25 orang yang sebagian besar merupakan warga ibu-ibu dan beberapa perangkat desa.

Setelah kegiatan sosialisasi di Aula Kantor Desa Suka Makmur, Tim PkM bersama jajaran pemerintah dan beberapa masyarakat desa meninjau lokasi PLTS untuk melakukan survei dan beberapa arahan terkait metode dan cara-cara yang perlu dilakukan dalam pengelolaan sistem pembangkit listrik alternatif. Hal ini dilakukan untuk mengukur sejauh mana pemahaman dan kemampuan masyarakat dalam mengelola dan menggunakan pembangkit listrik alternatif tersebut.

\section{HASIL DAN PEMBAHASAN}

Pelaksanaan PkM di Desa Suka Makmur secara garis besar dilaksanakan dalam dua tahapan, yaitu tahapan sosialisasi dan pelatihan sistem penbangkit listrik alternatif. Tujuan pelaksanaan kegiatan $\mathrm{PkM}$ ini antara lain:

1. Mensosialisasikan mekanisme dan tata cara pengelolaan sistem pembangkit listrik alternatif.

2. Mengetahui sejauh mana kemampuan masyarakat dalam pemberdayaan pengelolaan sistem pembangkit listrik alternatif.

\section{Survei Lokasi}

Kegiatan ini adalah langkah awal dalam pelaksanaan $\mathrm{PkM}$ dengan tujuan untuk mengetahui dan menentukan tempat yang 
layak untu dijadikan sasaran dalam pengabdian. Kegiatan ini dilakukan melalui tinjauan ke tempat-tempat yang dianggap layak sebagai sasaran pengabdian. Peninjauan ini didasarkan dari berbagai informasi dari sumber-sumber yang menjadi indikator kelayakan suatu tempat dijadikan lokasi pengabdian. Berkaitan dengan sistem pembangkit listrik, berdasarkan informasi yang dikumpulkan ditetapkan bahwa daerah Kec. Bulango Ulu merupakan daerah yang tepat untuk dijadikan lokasi pengabdian. Pasalnya di kecamatan tersebut ada beberapa desa yang terdapat sistem pembangkit listrik alternatif, khususnya di Desa Pilolaheya dan Suka Makmur. Kondisi daerah tersebut merupakan daerah berbukit (Gambar 4) dan secara umum mata pencaharian mereka adalah petani jagung dan gula aren. Disamping itu, sumber air yang mereka gunakan berasal dari sungai yang ada di desa tersebut (Gambar 5).

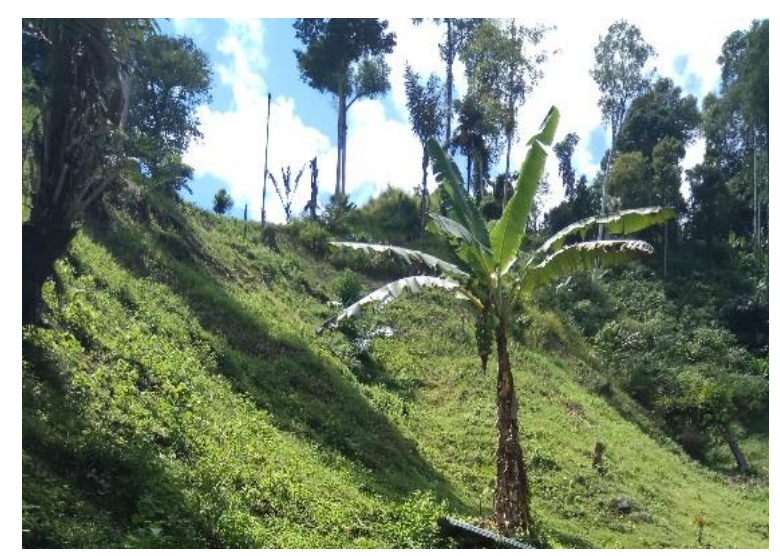

Gambar 4. Kondisi Umum Wilayah Desa Suka Makmur dan Pilolaheya

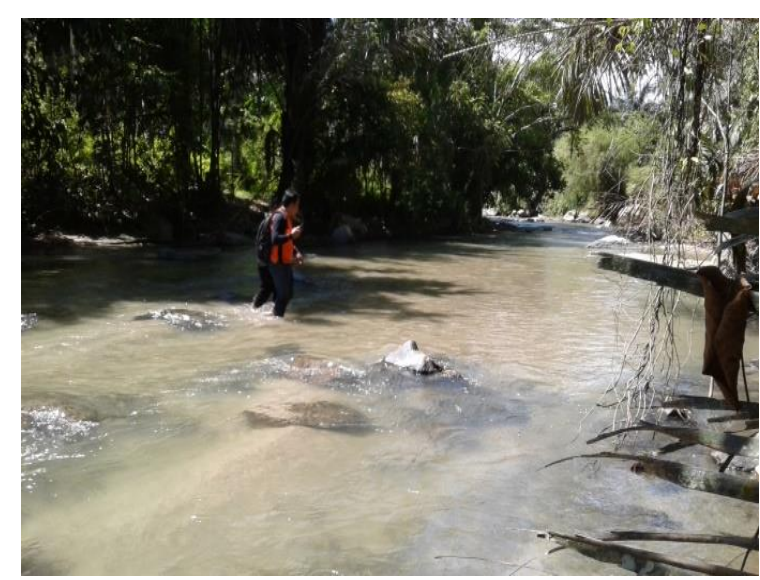

Gambar 5. Sungai di sekitar Desa Suka Makmur dan Pilolaheya

\section{Koordinasi dan Persiapan Pelaksanaan PkM}

Koordinasi berkaitan dengan kesediaan dan kesiapan daerah sasaran sebagai lokasi pengabdian. Koordinasi ini dilakukan melalui pemberitahuan kepada Kepala Desa yang menjadi sasaran pengabdian.

Persiapan pelaksanaan pengabdian dilakukan sebelum pelaksanaan sosialisasi dan kegiatan pelatihan pemberdayaan pengelolaan sistem pembangkit listrik. Kegiatan ini dimaksudkan untuk menyiapkan segala bentuk yang digunakan dalam pelaksanaan pengabdian masyarakat. Kegiatan persiapan ini dilakukan dengan tahapan berikut.

- Pengurusan administrasi. Dalam pengurusan administrasi, dokumen yang diperlukan antara lain surat izin Kepala Desa untuk melaksanakan pengabidan di desa tersebut, surat tugas dari UPPM Poligon dan SPPD (perjalanan dinas).

- Perlengkapan. Perlengkapan yang dimaksud adalah alat-alat yang diperlukan saat melakukan pengabdian, diantaranya materi sosialisasi, LCD Proyektor, dan Laptop.

- Disamping itu, aspek lain yang menjadi unsur penting dalam persiapan pelaksanaan pengabdian adalah mengkonfirmasi dan koordinasi kesediaan masyarakat desa sebagai peserta pengabdian, terutama dalam pelaksanaan sosialisasi (Gambar 6).

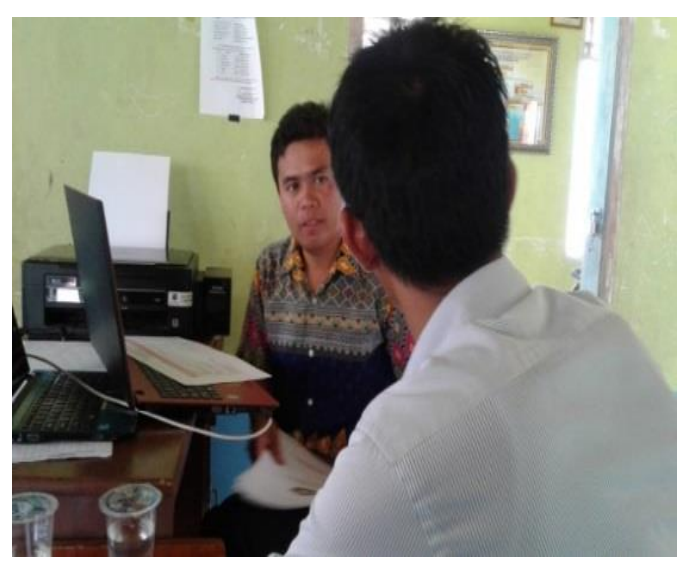

Gambar 6. Koordinasi dengan Pihak Desa

\section{Sosialisasi}

Sosialisasi dilaksanakan di Aula kantor Desa Suka Makmur yang dihadiri oleh masayarakatr desa yang berjumlah lebih dari 25 peserta yang didominasi oleh ibu-ibu rumah tangga. Disamping itu, beberapa jajaran pemerintah desa juga ikut serta dalam 
pelaksanaan sosialisasi tersebut. Kegiatan sosialisasi ini dimaksudkan untuk memberikan pengetahuan dan pemahaman kepada masyarakat terkait dengan konservasi dan pemberdayaan pengelolaan sistem pembangkit listrik alternatif. Harapannya adalah masyarakat dapat mengelola sistem pembangkit yang ada di desa tersebut, baik dari cara penggunaannya, pemeliharaannya serta dari segi penyelesaian permasalahan yang terkait dengan sistem pembangkit listrik alternatif. Dengan begitu penggunaaan sistem pembangkit listrik dapat terkontrol dengan baik. Kegiatan sosialisasi ini dilaksanakan melalui kegiatan-kegiatan berikut.

1. Sambutan dan pembukaan oleh Kepala Desa Suka Makmur (Gambar 7). Dalam sambutannya, kepala desa menyatakan bahwa pihaknya sangat merespon positif kedatangan Tim Pengabdian yang menyempatkan waktu untuk melakukan kegiatan PkM di Desa Suka Makmur. Pasalnya, desa tersebut merupakan desa yang paling ujung di Kecamatan Bulango Ulu dan medan yang ditempuh menujum ke desa tersebut masih sangat terjal dan sulit untuk dijangkau dengan mobil.

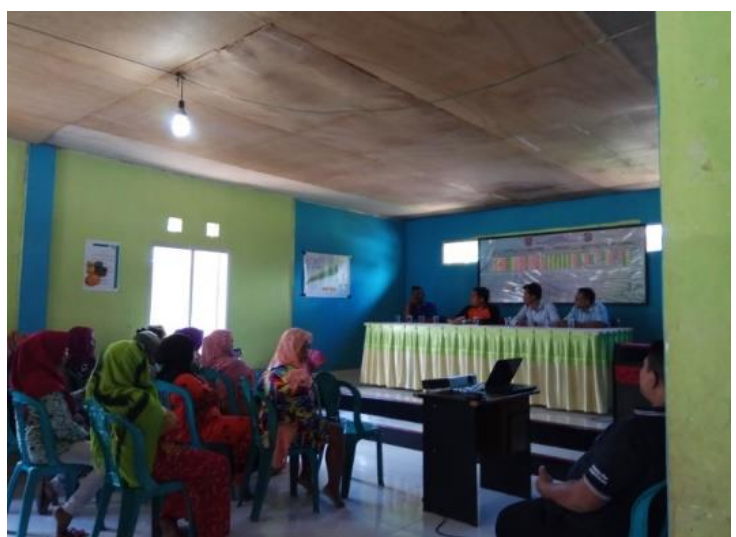

Gambar 7. Sambutan Kepala Desa Suka Makmur

2. Penyampaian materi sosialisasi. Materi sosialisasi disampaikan oleh Ketu Tim Pengabdian (Gambar 8) dan dilanjutkan oleh anggota tim lainnya. Dalam kegiatan ini antusias masyarakat sangat bagus. Hal ini dibuktikan dengan banyak pertanyaan dari masyarakat (Gambar 9) terkait dengan sistem pembangkit listrik alternatif, khususnya Pembangkit Listrik Tenaga Surya (PLTS).

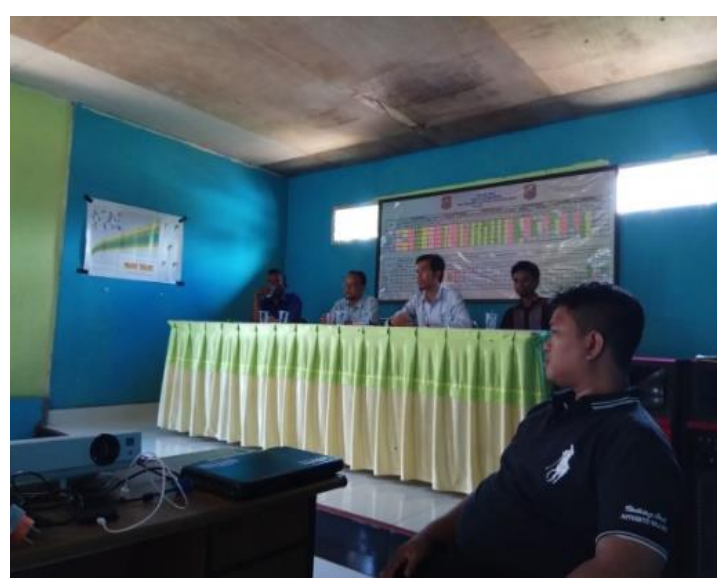

Gambar 8. Penyampaian Materi Sosialisasi oleh Tim Pengabdian

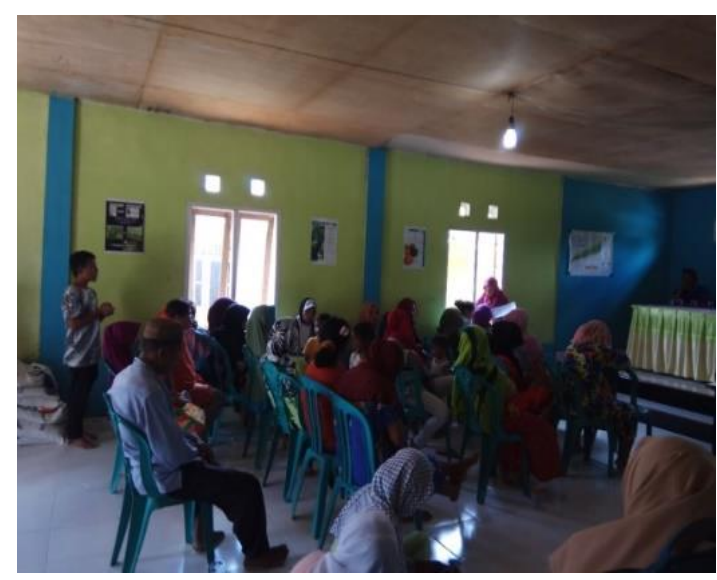

Gambar 9. Proses Diskusi dan Tanya Jawab

\section{Pelaksanaan Konservasi dan Pemberdayaan Sistem Pembangkit Listrik Alternatif}

Pembangkit listrik alternatif, khususnya PLTS yang ada di Desa Suka Makmur merupakan pembangkit yang hanya dimanfaatkan untuk memompa air yang digunakan untuk memenuhi kebutuhan masyarakat. Hal ini karena sumber air sangat sedikit. Jika masyarakat melakukan pengeboran untuk membuat sumur, maka dalam pengerjaannya membutuh tenaga yang sangat besar tidak hanya saat pembuatan sumur tapi pada saat pengambilan air. Pasalnya sumber air di daerah tersebut sangat dalam dan akan ditemukan pada kedalaman tertentu. 
Oleh karena itu PLTS yang ada digunakan untuk tenaga pompa air. Untuk penerangan, masyarakat masih terbatas pada mesin yang sederhana. Diantara masyarakat juga masih terbatas pada lampu lilin atau pelita. Pelaksanaan konservasi dan pemberdayaan sistem pembangkit dilaksanakan setelah pelaksanaan sosialisasi. Hal ini dimaksudkan untuk mengukur sejauh mana pemahaman masyarakat akan pentingnya pengelolaan sistem pembangkit listrik alternatif. Kegiatan dilaksanakan secara langsung ke lokasi PLTS yang ada di desa tersebut yang dipandu oleh Ketua Tim Pengabdian (Gambar 10).

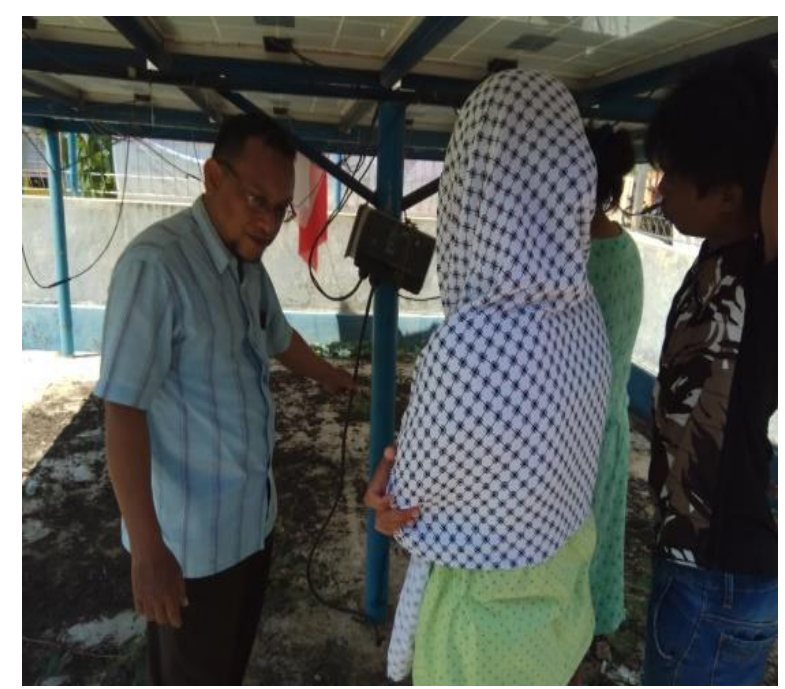

Gambar 10. Arahan Tim dalam Konservasi dan Pemberdayaan Pengelolaan Sistem Pembangkit Listrik Alternatif

Disamping arahan dan materi tambahan, ketu tim mendemokan bagaimana caranya metode pengelolaan sistem poembangkit listrik alternatif, khususnya PLTS. Berdasarkan hal tersebut diketahui bahwa adanya kesadaran masyarakat akan pentingnya mengelola sistem pembangkit ini. Hal ini agar penggunaan sistem pembangkit dapat dikontrol dengan baik sehingga mengurangi kerusakan secara dini dan pemakaian secara optimal.

\section{PENUTUP}

\section{Kesimpulan}

Berdasarkan hasil kegiatan PkM dapat diambil bebereapa kesimpulan, diantaranya:

1. Kebutuhan masyarakat akan listrik sudah pada kondisi yang sangat kritis.
2. Masyarakat masih terbatas sebagai pengguna PLTS tanpa mampu mengelola dengan baik.

3. Adanya antusias dan kesadaran masyarakat akan pentingnya konservasi dan pemberdayaan pengelolaan sistem pembangkit listrik alternatif.

\section{Saran}

1. Diperlukan adanya sistem pengontrolan yang teratur oleh pemerintah dalam pengelolaan sistem pembangkit listrik alternatif.

2. Perlu adanya manual procedure (Buku Panduan) yang dapat digunakan oleh masyarakat untuk membantu dalam pengontrolan sistem pembangkit listrik alternatif.

\section{DAFTAR PUSTAKA}

Asy'ari, H., 2015, Pemanfaatan Solar Cell dengan PLN sebagai Sumber Energi Listrik Rumah Tinggal. Jurnal Emitor, 14(1).

Dewi, A.Y., 2013. Pemanfaatan Energi Surya sebagai Suplai Cadangan pada Laboratorium Elektro Dasar di Institut Teknologi Padang. Jurnal Teknik Elektro, 2(3).

Hikmawan, A., 2012, Simulasi Hybrid Power System Antara Photovoltaik dengan Fuel Cell Menggunakan Fuzzy Logic Controller. Jurusan Teknik Elektro Universitas Jember.

Saad, R.T., 2011, Peranan Teknologi Solar Cell dalam Peningkatan Daya Saing Usaha Kecil. Jurnal Ilmiah Semesta Teknika, 14, 58-63.

Subandi, 2015, Pembangkit Listrik Energi Matahari sebagai Penggerak Pompa Air dengan Menggunakan Solar Cell. Jurnal Teknologi Technoscientia, 7(2).

Ubaidillah, 2012, Pengembangan Piranti Hibrid Termoelektrik-Sel Surya sebagai Pembangkit Listrik Rumah Tangga. Jurnal Litbang Provinsi Jawa Tengah, 10(2). 
Yuliananda, S., 2015, Pengaruh Perubahan

Intensitas Matahari terhadap Daya

Keluaran Panel Surya. Jurnal

Pengabdian LPPM Untag Surabaya,

01, 193 - 202. 